\title{
P2 purinergic receptor modulation of cytokine production
}

\author{
Christopher A. Gabel
}

Received: 12 December 2005 / Accepted: 10 January 2006 / Published online: 3 January 2007

(C) Springer Science + Business Media B.V. 2007

\begin{abstract}
Cytokines serve important functions in controlling host immunity. Cells involved in the synthesis of these polypeptide mediators have evolved highly regulated processes to ensure that production is carefully balanced. In inflammatory and immune disorders, however, misregulation of the production and/or activity of cytokines is recognized as a major contributor to the disease process, and therapeutics that target individual cytokines are providing very effective treatment options in the clinic. Leukocytes are the principle producers of a number of key cytokines, and these cells also express numerous members of the purinergic P2 receptor family. Studies in several cellular systems have provided evidence that P2 receptor modulation can affect cytokine production, and mechanistic features of this regulation have emerged. This review highlights three separate examples corresponding to (1) $\mathrm{P}_{2} \mathrm{Y}_{6}$ receptor mediated impact on interleukin (IL)-8 production, (2) $\mathrm{P} 2 \mathrm{Y}_{11}$ receptor-mediated affects on IL-12/23 output, and (3) $\mathrm{P} 2 \mathrm{X}_{7}$ receptor mediated IL-1 $\beta$ posttranslational processing. These examples demonstrate important roles of purinergic receptors in the modulation of cytokine production. Extension of these cellular observations to in vivo situations may lead to new therapeutic strategies for treating cytokine-mediated diseases.
\end{abstract}

Key words cytokines $\cdot$ dendritic cells $\cdot$ interleukin-1 interleukin- 8 - interleukin- $12 \cdot$ monocytes $\cdot$ nucleotides . purinergic receptors $\cdot$ tumor necrosis factor

\footnotetext{
C. A. Gabel $(\bowtie)$

Department of Inflammation, Amgen, Inc.,

1201 Amgen Court West,

Seattle, WA 98119, USA

e-mail: gabel@amgen.com
}

\author{
Abbreviations \\ LPS lipopolysaccharide \\ RA rheumatoid arthritis \\ IL interleukin \\ TNF tumor necrosis factor \\ IFN interferon \\ ERK extracellular signal regulated kinase \\ LDH lactate dehydrogenase \\ $\mathrm{PGE}_{2}$ prostaglandin $\mathrm{E}_{2}$ \\ GPCR $G$ protein coupled receptor \\ BZATP benzoylbenzoyl-ATP
}

\section{Introduction}

Cytokines comprise a heterogeneous group of polypeptides that mediate a variety of biological responses following their binding to specific receptors on target cells and tissues. Historically, cytokines (including lymphokines) were identified as leukocyte-derived soluble mediators that, when added to other leukocytes and/or to non-leukocyte targets, altered cellular behavior. Today, however, we realize that individual cytokines can be generated by cells of immune as well as non-immune origin, and that these polypeptides orchestrate a complex system of checks and balances controlling host immune and inflammatory processes. Our understanding of the importance that cytokines and cytokine signaling mechanisms serve in host defense mechanisms has been bolstered by the identification of genetic mutations within cytokine and/or cytokine receptor signaling complex genes that profoundly affect pathogen susceptibility $[1,2]$. Likewise, genetically engineered mice that lack individual cytokines and/or cytokine receptors have provided a greater understanding of the capabilities 
possessed by these signaling molecules for promoting inflammatory and autoimmune states [3]. Moreover, the critical importance served by cytokines in mediating inflammation and autoimmunity has been underscored by the recent success of anti-cytokine biologics in the treatment of inflammatory diseases such as rheumatoid arthritis (RA) and Crohn's disease. For example, agents that neutralize tumor necrosis factor (TNF) $\alpha$ (Enbrel, Remicade and Humira) have dramatically improved the treatment of RA [4-6]. In addition, the natural interleukin (IL)-1 receptor antagonist (Kineret) provides therapeutic benefit to RA patients and is reported to yield remarkable clinical outcomes when administered to patients suffering from a group of rare hereditary autoinflammatory disorders such as Muckle-Wells syndrome [7-9]. Ongoing clinical trials with agents that target IL-12 likewise are showing encouraging efficacy in the treatment of psoriasis and Crohn's disease $[10,11]$, and the list of anti-cytokine therapies entering clinical trials grows regularly [6]. Thus, cytokines and the signaling pathways engaged after they bind to receptors on cells represent attractive therapeutic targets for intervention of human autoimmune and inflammatory diseases. Studies over the past decade have suggested that purinergic receptor function, involving both $\mathrm{P} 2 \mathrm{Y}$ and $\mathrm{P} 2 \mathrm{X}$ family members, can modulate cytokine production and/or activity. This review focuses on several cellular systems where purinergic modulation of cytokine production has been demonstrated and mechanistic explanations have been sought. The cited studies signify that nucleotide receptormediated signaling can affect output of several important cytokines. In this context, pharmacological modulation of P2 receptors may represent a new therapeutic modality for treatment of cytokine-mediated disease processes in the future.

\section{Leukocyte expression of nucleotide receptors}

Essentially all leukocyte populations express members of the P2 purinergic receptor superfamily; several recent reviews have detailed receptor expression patterns and the reader is directed to these for a more complete description $[12,13]$. Human monocytes, for example, express mRNA encoding $\mathrm{P}_{2} \mathrm{Y}_{1}, \mathrm{P} 2 \mathrm{Y}_{2}, \mathrm{P} 2 \mathrm{Y}_{4}, \mathrm{P} 2 \mathrm{Y}_{6}, \mathrm{P} 2 \mathrm{X}_{1}$ and $\mathrm{P} 2 \mathrm{X}_{7}$ receptors [14-16]. Human lymphocytes similarly express mRNAs encoding $\mathrm{P}_{2} \mathrm{Y}_{1}, \mathrm{P}_{2} \mathrm{Y}_{2}, \mathrm{P}_{2} \mathrm{Y}_{4}, \mathrm{P}_{2} \mathrm{Y}_{6}$ receptors and members of the $\mathrm{P} 2 \mathrm{X}$ family, including $\mathrm{P} 2 \mathrm{X}_{7}$, are detected in both $\mathrm{B}$ and T-lymphocyte populations [15, 17-21]. Circulating human neutrophils express $\mathrm{P}_{2} \mathrm{Y}_{4}$ and $\mathrm{P}_{2} \mathrm{Y}_{6}$ mRNAs, and the $\mathrm{P}_{2} \mathrm{X}_{7}$ receptor is reported to be present in these cells [22]. Human eosinophils and murine mast cells also are reported to contain the $\mathrm{P} 2 \mathrm{X}_{7}$ receptor $[23,24]$ as are rodent peritoneal macrophages $[25,26]$; historically, many
ATP-dependent responses observed using murine macrophages were associated with activation of the $\mathrm{P} 2 \mathrm{Z}$ receptor $[27,28]$. Cloning and characterization of the $\mathrm{P} 2 \mathrm{X}_{7}$ receptor revealed that this polypeptide possessed functional attributes previously ascribed to the P2Z receptor [29, 30]. Thus, reference to the $\mathrm{P} 2 \mathrm{Z}$ receptor was discontinued in favor of the $\mathrm{P} 2 \mathrm{X}_{7}$ receptor designation. Murine spleen macrophages, as well as the macrophage-like cell line J774, express multiple P2X and P2Y subtypes [31]. Murine and rat microglial cells, the brain's macrophage, also abundantly express $\mathrm{P}_{2} \mathrm{X}_{7}$ receptors $[32,33]$.

A functional consequence often attendant to activation of the $\mathrm{P} 2 \mathrm{X}_{7}$ receptor is the opening of a nonselective pore that is permeable to large fluorescent molecules such as YoPro Yellow. Interestingly, the ability of monocytes and monocyte-like cells to demonstrate this pore activity is influenced by conditions under which these cells are cultured, suggesting that functional output of the $\mathrm{P}_{2} \mathrm{X}_{7}$ receptor can be regulated [34-36]. Human monocytes demonstrate a change in receptor functionality without a corresponding change in the level of receptor mRNA expression, suggesting that receptor function can be regulated via posttranslational mechanisms [16].

Dendritic cells, which specialize in antigen presentation and are key producers of cytokines involved in maintenance of acquired immunity, also express members of the P2 receptor superfamily. Human monocyte-derived dendritic cells are reported to express mRNA for $\mathrm{P}_{2} \mathrm{Y}_{1}, \mathrm{P}_{2} \mathrm{Y}_{2}, \mathrm{P}_{2} \mathrm{Y}_{4}$, $\mathrm{P} 2 \mathrm{Y}_{5}, \mathrm{P} 2 \mathrm{Y}_{6}, \mathrm{P} 2 \mathrm{Y}_{10}, \mathrm{P} 2 \mathrm{Y}_{11}$, and $\mathrm{P} 2 \mathrm{Y}_{13}$ from the $\mathrm{P} 2 \mathrm{Y}$ receptor side of the family and $\mathrm{P} 2 \mathrm{X}_{1}, \mathrm{P} 2 \mathrm{X}_{4}, \mathrm{P} 2 \mathrm{X}_{5}$, and $\mathrm{P}_{2} \mathrm{X}_{7}$ from the P2X receptor lineage [37-39]. Murine dendritic cell lines also express the $\mathrm{P} 2 \mathrm{X}_{7}$ receptor [40].

\section{P2Y receptor-dependent regulation of cytokine production}

$P 2 Y_{6}$ receptor-mediated effects The $\mathrm{P}_{2} \mathrm{Y}_{6}$ receptor is selectively activated via UDP [41], and effects observed with this nucleotide often are attributed to activation of this receptor. Several studies have linked $\mathrm{P}^{2} \mathrm{Y}_{6}$ function to IL8 expression, a cytokine originally isolated as a neutrophil chemotactic factor and now designated as a member of the CXC family of chemokines [42]. IL-8 functions to promote influx of neutrophils to sites of injury and/or infection, and overproduction of IL-8 may contribute to several pathophysiological conditions including chronic lung inflammation and cancer [43]. When human monocytic THP-1 cells are treated with UDP, IL-8 output is enhanced and prior treatment of the cells with a $\mathrm{P}_{2} \mathrm{Y}_{6}$ antisense oligonucleotide attenuates the magnitude of the cytokine response [44]. Likewise, $\mathrm{P}_{2} \mathrm{Y}_{6}$ receptor transfected $1321 \mathrm{~N}$ cells secrete greater levels of IL-8 in response to UDP challenge than do 
their non-transfected counterparts [44]. Similarly, human promonocytic U937 cells stably transfected with human $\mathrm{P}^{2} \mathrm{Y}_{6}$ receptor secrete IL-8 when stimulated with UDP [45]. $\mathrm{P}_{2} \mathrm{Y}_{6}$ receptor-transfected U937 cells also generate TNF $\alpha$ and the chemokines MCP-1 and IP-10 in response to UDP activation. In contrast, UDP-challenged $\mathrm{P}_{2} \mathrm{Y}_{6}$ receptor $1321 \mathrm{~N}$ cell transfectants produce IL-8 but not other cytokine products [45]. The distinct response patterns displayed by the two transfected cell lines suggest that the cellular context in which the $\mathrm{P}_{2} \mathrm{Y}_{6}$ receptor is placed impacts the pattern of cytokines/chemokines expressed. Interestingly, output of IL-8 from LPS stimulated THP-1 cells is decreased when apyrase is included in the cell culture medium [44], suggesting that nucleotides are released in response to LPS activation and these, in turn, activate purinergic receptors in an autocrine type of mechanism.

The mechanism by which the $\mathrm{P}_{2} \mathrm{Y}_{6}$ receptor activates cytokine output has received limited investigation. The $\mathrm{P} 2 \mathrm{Y}_{6}$ receptor is a $\mathrm{G}_{\mathrm{q}}$-coupled receptor $[13,46,47]$ and thus is expected to promote activation of phospholipase $\mathrm{C}$ leading to the generation of inositol-1,4,5-triphosphate and elevation of intracellular $\mathrm{Ca}^{2+}$ levels. In $\mathrm{P}_{2} \mathrm{Y}_{6}$ receptor expressing THP-1 cells, the extracellular signal-regulated kinase (ERK) antagonist PD98059 impairs UDP-induced IL-8 output whereas the p38 stress kinase antagonist SB203580 is without effect. Thus, in this system the $\mathrm{P}^{2} \mathrm{Y}_{6}$ receptor-induced rise in intracellular $\mathrm{Ca}^{2+}$ appears to be coupled to an ERK-activated signaling cascade leading to IL-8 expression [44]. In osteoclasts, activation of the $\mathrm{P}_{2} \mathrm{Y}_{6}$ receptor via UDP or the selective receptor agonist INS48823 induces a transient rise in intracellular $\mathrm{Ca}^{2+}$ and activation of the transcription factor NF- $\mathrm{KB}$ [48]. Although cytokine output was not examined in the osteoclast system, activation of NF-KB often is associated with expression of cytokine genes [49] and oscillations in intracellular $\mathrm{Ca}^{2+}$ concentrations have been linked to activation of this transcription factor [50].

With respect to inflammatory disease processes, no specific role for $\mathrm{P}_{2} \mathrm{Y}_{6}$ receptors has been reported. However, tissue sections obtained from patients with inflammatory bowel disease are reported to contain T-cells within inflammatory lesions possessing enhanced expression of the $\mathrm{P}_{2} \mathrm{Y}_{6}$ receptor [51]. As such, $\mathrm{P}_{2} \mathrm{Y}_{6}$ receptor expression on T-cells may be upregulated at sites of inflammation and/or T-cells expressing this receptor may be preferentially recruited to these sites.

$P 2 Y_{11}$ receptor-mediated effects impact dendritic cell function The $\mathrm{P}_{2} \mathrm{Y}_{11}$ receptor prefers ATP as it's ligand, and the non-hydrolyzable ATP analog ATP $\gamma \mathrm{S}$ often is employed in vitro as a surrogate ligand; the latter is not, however, a selective agonist of the $\mathrm{P}_{2} \mathrm{Y}_{11}$ receptor $[41,47]$.
$\mathrm{P} \mathrm{Y}_{11}$ receptor modulation of cytokine generation has been studied in some detail with human dendritic cells, with production of IL-12 being a major focus of these studies. IL-12 is composed of two distinct subunits, p40 and p35, which are covalently linked via an intermolecular disulfide bond to form the biologically active $\mathrm{p} 70$ species [52-54]. A related cytokine, IL-23, is composed of the same p40 subunit covalently bound to a unique p19 subunit $[53,54]$. IL-12 and IL-23 are produced in abundance by activated antigen presenting cells such as monocytes and dendritic cells. When bound to target receptors on T-lymphocytes and natural killer (NK) cells, IL-12 activates interferon (IFN) $\gamma$ output, alters T-cell development, and affects NK cell killer activity [55]. IL-23 also activates T-cells and promotes IFN $\gamma$ output, but in this case the responding lymphocytes appear to represent a unique subpopulation of memory T-cells specializing in the production of the proinflammatory cytokine IL-17 [56, 57]. Together, IL-12 and IL-23 cooperate to shift the immune system toward a T helper (Th) 1 state that is characteristic of inflammatory diseases such as RA and inflammatory bowel disease [58].

Application of ATP to human monocyte-derived dendritic cells (i.e., monocytes cultured for 6 days in the presence of granulocyte macrophage colony stimulating factor and IL-4) originally was reported to enhance expression of several cell surface molecules and to increase output of IL-12; this ATP effect was augmented by costimulation with TNF $\alpha$ [59]. Likewise, ATP but not UTP was reported to enhance expression of CXC chemokine receptor 4 by dendritic cells [60]. In these studies, the nature of the specific $\mathrm{P} 2$ receptor subtype(s) responsible for the dendritic cell cytokine response was not addressed.

While the above studies suggested that nucleotides may directly regulate cytokine output, more recent studies conducted with dendritic cells have focused on the role of extracellular nucleotides as modulators of cytokine output induced by other stimuli. For example, treatment of human monocyte-derived dendritic cells with either LPS or CD40 ligand promotes secretion of IL- $1 \alpha$, IL- $1 \beta, \mathrm{TNF} \alpha$, IL-6, and IL-12 (p70), and co-addition of ATP $(250 \mu \mathrm{M})$ along with the activation stimulus inhibits cytokine output [61]. In this same dendritic cell system, ATP does not inhibit output of IL-10 or IL-1 receptor antagonist, two cytokines possessing anti-inflammatory properties. The dendritic cell purinergic receptor responsible for the cytokine modulatory effects was not identified in this system, but the effect of ATP was mimicked by ADP but not by UTP.

In contrast to the simple pattern of cytokine inhibition noted above, other studies conducted with monocytederived dendritic cells suggest that the response elicited by extracellular nucleotides is complex in nature and dependent on the quantity of cytokine produced. For example, monocyte-derived dendritic cells treated with 
TNF $\alpha$ or LPS generate greater quantities of IL-12 when simultaneously challenged with ATP (the ELISA kit employed in this study measured both IL-12p40 and IL12p70). Comparison of the effectiveness of several ATP analogs suggests that the $\mathrm{P}_{2} \mathrm{Y}_{11}$ receptor is responsible for enhancing cytokine expression [62]. In an extension of these findings, monocyte-derived macrophages were activated with a panel of different agonists (TNF $\alpha$, LPS, or soluble CD40 ligand) in the absence or presence of ATP $\gamma$ S [63]. At agonist concentrations yielding low levels of IL$12 \mathrm{p} 40$ and TNF $\alpha$ output, ATP $\gamma \mathrm{S}(200 \mu \mathrm{M})$ increases secreted levels of these two polypeptides. However, at agonist concentrations yielding higher levels of IL-12p40 and TNF $\alpha$ output, ATP $\gamma \mathrm{S}$ inhibits their output. Notably, LPS (but not TNF $\alpha$ or CD40) stimulates secretion of the bioactive, heterodimeric form of IL-12 (i.e., IL-12p70) and ATP $\gamma \mathrm{S}$ antagonizes IL-12p70 output at all tested LPS concentrations. It is known from other studies that the p40 and p35 subunits of IL-12 can be regulated independently [64]; lack of coordinated synthesis may help to explain why ATP $\gamma \mathrm{S}$ can enhance IL-12p40 but inhibit IL-12p70 output in response to LPS challenge.

The ATP response observed in the dendritic cell system assumes an even greater complexity when the output of IL12 and IL-23 are compared. Human monocyte-derived dendritic cells activated with intact $E$. coli produce both IL12 and IL-23. In response to this challenge, IL-12p40, IL12 p35, and IL-23p19 message levels increase and levels of IL-12 and IL-23 released extracellularly increase accordingly [65]. Addition of ATP $(250 \mu \mathrm{M})$ to the medium during bacterial challenge decreases IL-12p40 and IL12 p35 message levels but increases IL-23 message levels. Likewise, whereas E. coli-induced secretion of IL-12p70 and IL-12p40 from dendritic cells is inhibited by ATP, secretion of bioactive IL-23 is enhanced. Since both IL-12 and IL-23 share the IL-12p40 subunit, the opposite effects achieved by ATP with respect to output of these two cytokines is somewhat surprising. However, this may reflect that synthesis of the p40 subunit can exceed that of the p19 subunit and secretion of the bioactive IL-23 heterodimer requires simultaneous expression of both subunits [66]. ATP $\gamma \mathrm{S}$ and AR-C67085 (a synthetic nucleotide analog) are more potent than ATP at inhibiting E. coliinduced output of IL-12p70 and IL-12p40. In contrast, these two nucleotides are ineffective as enhancers of IL-23; ADP, however, is as effective as ATP at enhancing E. coliinduced IL-23 output. On this basis, it was concluded that the $\mathrm{P} 2 \mathrm{Y}_{11}$ receptor is responsible for the nucleotidemediated antagonism of IL-12 production whereas a separate, ADP-sensitive P2 receptor subtype is responsible for promoting IL-23 production [65].

Sorting out the identity of $\mathrm{P} 2$ receptors that mediate the aforementioned effects of nucleotides on dendritic cell cytokine output is complicated by the existence of cell surface nucleotidases such as CD39 [37]. These enzymes can act on exogenously added nucleotides to generate metabolites that may possess altered selectivity for P2 receptors relative to the parent nucleotide originally added to the culture medium. In this light, it is interesting to note that ADP and several related nucleotides also are reported to inhibit IL-12p70, IL-12p40, and TNF $\alpha$ output from LPSactivated dendritic cells [67]. Based on the inability of ADP to act as an agonist of the $\mathrm{P} 2 \mathrm{Y}_{11}$ receptor and the nature of the signaling response induced by this nucleotide, the cytokine modulatory effects induced by ADP in this system may reflect activation of a novel dendritic cell $\mathrm{P} 2$ receptor subtype [67].

Mechanistic features attendant to $\mathrm{P} 2 \mathrm{Y}_{11}$ receptor activation have been investigated and changes to intracellular cAMP concentrations appear important to the cytokine modulatory response. The $\mathrm{P}_{2} \mathrm{Y}_{11}$ receptor employs both Gq- and Gs-type G-proteins in mediating signaling [47]; the $\mathrm{P} 2 \mathrm{Y}_{11}$ receptor is unique amongst $\mathrm{P} 2$ receptors in its ability to employ Gs and, in turn, to activate adenylate cyclase. Activation of adenylate cyclase and the associated rise in cAMP levels appear to be responsible for both the ATPinduced rise in IL-23 and decline in IL-12 from E. coliinduced human dendritic cells. This conclusion is based on several observations. First, substitution of prostaglandin $E_{2}$ $\left(\mathrm{PGE}_{2}\right)$ for ATP in the dendritic cell system produces a similar outcome with respect to inhibition of IL-12 and augmention of IL-23 output $[63,65]$. PGE $_{2}$ signals via Gprotein-coupled prostaglandin receptors, and two of these receptors, $\mathrm{EP}_{2}$ and $\mathrm{EP}_{4}$, transmit signals via Gs [68]. Studies conducted in genetically altered mice support the involvement of the $\mathrm{EP}_{4}$ receptor in mediating the inhibitory effect on IL-12 production; LPS-activated bone marrowderived macrophages derived from wild-type mice but not from $\mathrm{EP}_{4}$ receptor-deficient animals produce less IL-12 in the presence of $\mathrm{PGE}_{2}$ [69]. Second, activation of other $\mathrm{G}$ protein coupled receptors (GPCRs) that engage adenylate cyclase, such as histamine $(\mathrm{H} 2)$ and adenosine A2a receptors, inhibit IL-12 output [70]. Third, the ability of ATP analogs to alter IL-12 output correlates with their impact on intracellular cAMP levels [62]. Finally, treatment of E. coli-activated dendritic cells with forskolin, an agent that activates adenylate cyclase independently of GPCR activation, also inhibits IL-12 (protein) output while enhancing IL-23p19 (message) expression [65]. In view of the ability of the aforementioned agents to elevate cAMP and to produce reciprocal effects on IL-12 and IL-23 output from dendritic cells, it is surprising that ATP $\gamma \mathrm{S}$ and ARC67085, two effective agonists of the $\mathrm{P}_{2} \mathrm{Y}_{11}$ receptor, cause inhibition of IL-12 output without enhancing IL-23 expression [65]. Notably, ADP is able to enhance IL-23p19 message expression by E. coli-activated dendritic cells [65]. 
The reciprocal effects observed with respect to production of IL-12 and IL-23 in the presence of ATP, therefore, may reflect activation of the $\mathrm{P}_{2} \mathrm{Y}_{11}$ receptor by ATP and, as a result of hydrolysis of the added ATP via ecto-nucleotidases, simultaneous activation of a novel type of $\mathrm{P} 2$ receptor that is activated via ADP and coupled to Gs.

Although dendritic cell cytokine output is well documented to be subject to regulation via nucleotides in vitro, there is little information to suggest that this type of regulation takes place in vivo. A recent report noted, however, that intradermal injection of ATP $\gamma \mathrm{S}$ into mice results in an enhanced contact hypersensitivity response, and this effect may be achieved as a result of activation of Langerhans cells, a subclass of dendritic cells [71]. Murine Langerhans cells, like other dendritic cells, express the ecto-nucleotidase CD39, and CD39-deficient mice display an exacerbated skin inflammatory response when irritant chemicals such as croton oil are applied topically [72].

\section{P2X receptor-dependent regulation of cytokine production}

With the exception of the $\mathrm{P}_{2} \mathrm{X}_{7}$ receptor, functional responses attendant to activation of $\mathrm{P} 2 \mathrm{X}$ receptor family members are not generally associated with cytokine modulation. Members of this family certainly can impact inflammatory processes as evidenced by the attenuated pain responses observed following administration of selective $\mathrm{P} 2 \mathrm{X}_{3}$ receptor antagonists to rodents [73]. These effects, however, are not directly linked to cytokine output but, rather, to effects associated with modulation of sensory afferent neurons. Therefore, a discussion of how P2X receptors affect cytokine output is limited in scope to the role of the $\mathrm{P}_{2} \mathrm{X}_{7}$ receptor. Although selective agonists and/ or antagonists of the $\mathrm{P} 2 \mathrm{X}_{7}$ receptor have to this point not been available, the $\mathrm{P}_{2} \mathrm{X}_{7}$ receptor possesses atypical features that often allow its function to be implicated during in vitro studies. Most notable amongst these features is the requirement that high ATP concentrations, often in excess of $500 \mu \mathrm{M}$, be employed to achieve receptor activation when cells are maintained in physiological media. Benzoylbenzoyl-ATP (BZATP) often is employed as an agonist of the $\mathrm{P} 2 \mathrm{X}_{7}$ receptor. Although this agent is reported to be a more effective agonist than ATP [74], it is not specific for the $\mathrm{P} 2 \mathrm{X}_{7}$ receptor [75]. Likewise, oxidized ATP often is employed as an antagonist of the P2 $\mathrm{X}_{7}$ receptor [76], but this agent also acts in a $\mathrm{P} 2$ receptorindependent manner [77].

$P 2 X_{7}$ receptor-mediated effects As noted earlier, the $\mathrm{P} 2 \mathrm{X}_{7}$ receptor is present on a number of leukocyte populations including monocytes and tissue macrophages. When challenged appropriately, cells of monocyte/macrophage lineage are abundant producers of proinflammatory cytokines including IL-1 and TNF $\alpha$. With respect to TNF $\alpha$ output, both enhancing and inhibitory responses have been associated with $\mathrm{P}_{2} \mathrm{X}_{7}$ receptor activation. Cultured rat microglia treated with $1 \mathrm{mM}$ ATP, for example, increase expression of TNF $\alpha$ mRNA and secrete this proinflammatory cytokine [78]. In this cellular system, the TNF $\alpha$-enhancing effect of ATP is dependent on an influx of extracellular calcium, and is suppressed by inhibitors of ERK (PD098059) and p38 (SB203580) mitogen activated kinases. Likewise, ATP is reported to enhance TNF $\alpha$ output from murine RAW 264.7 macrophages both in the absence and presence of LPS [79]; the purinergic receptor responsible for this effect in RAW cells is unknown. On the other hand, ATP is reported to inhibit TNF $\alpha$ release from LPS-activated murine peritoneal macrophages [80]; this antagonism does not appear to result from activation of the $\mathrm{P}_{2} \mathrm{X}_{7}$ receptor as UTP and UDP mimic the action of ATP but are not $\mathrm{P} 2 \mathrm{X}_{7}$ receptor agonists. Similarly, ATP inhibits LPS-induced release of TNF $\alpha$ from rat cortical astrocytes [81]. In this cellular system $\mathrm{mM}$ concentrations of ATP are required for the biological response, and the effect of ATP is mimicked by BZATP, properties consistent with involvement of the $\mathrm{P}_{2} \mathrm{X}_{7}$ receptor. Thus, the net effect observed with respect to ATP's ability to modulate $\mathrm{TNF} \alpha$ output is dependent on the cellular context.

The most extensively studied cytokine modulatory role involving the $\mathrm{P}_{2} \mathrm{X}_{7}$ receptor relates to its ability to promote IL-1 $\beta$ posttranslational processing. IL- $1 \beta$ is a multifaceted proinflammatory cytokine produced predominantly by cells of the monocyte/macrophage lineage [82]. Resting monocytes and macrophages do not constitutively produce IL$1 \beta$, but following challenge with an activating stimulus such as LPS, these cells rapidly engage in the production of large quantities of proIL-1 $\beta$. This precursor polypeptide (31 to $35 \mathrm{kDa}$ in mass) must be proteolytically processed by caspase-1 to generate the mature biologically active $17 \mathrm{kDa}$ cytokine species [83-85]. Importantly, proIL-1 $\beta$ lacks a leader sequence and, as a result, the newly synthesized polypeptides accumulate intracellularly within the cytosol of LPS-activated cells. In contrast to IL- $1 \beta$, caspase- 1 is constitutively expressed by monocytes and macrophages; this cysteine protease also resides in the cytoplasm as an inactive zymogen [86]. In the absence of additional stimulation, only a very low percentage of the newly synthesized proIL-1 $\beta$ polypeptides produced by LPStreated cells is processed by caspase- 1 and released extracellularly [87]. However, in the presence of an appropriate activation stimulus, procaspase- 1 is converted to its catalytically active form, proIL- $1 \beta$ subsequently is cleaved to its mature $17 \mathrm{kDa}$ species, and the mature 
cytokine is released extracellularly where it can engage receptors on target cells; a number of agents have been reported to facilitate this posttranslational processing in vitro including various toxins [88-92], defensin-like peptides [93, 94], and $\mathrm{K}^{+}$ionophores [95-97].

David Chaplin and his group first demonstrated that ATP can act as a trigger to promote IL-1 $\beta$ posttranslational processing from LPS-activated murine peritoneal macrophages [98]. When incubated in the absence of ATP, LPSactivated macrophages labeled with $\left[{ }^{35} \mathrm{~S}\right]$ methionine were shown to possess abundant quantities of the $35 \mathrm{kDa}$ proIL$1 \beta$ polypeptide, but radiolabeled cytokine products were not released extracellularly. Following addition of ATP to the medium, however, the LPS-activated $/\left[{ }^{35} \mathrm{~S}\right]$ methioninelabeled cells released IL- $1 \beta$ to the medium and the majority of the externalized cytokine was efficiently converted to the mature $17 \mathrm{kDa}$ species. The ATP-treated macrophages also released the cytoplasmic enzyme lactate dehydrogenase (LDH) and possessed a DNA fragmentation profile that was characteristic of an apoptotic cellular response. Although the identity of the receptor responsible for mediating these effects was not addressed, the high concentration of ATP employed $(5 \mathrm{mM})$ suggested $\mathrm{P} 2 \mathrm{X}_{7}$ receptor involvement. The ability of ATP to promote IL-1 $\beta$ posttranslational processing by murine peritoneal macrophages is not limited to in vitro cultures. Mice primed with LPS in vivo contain peritoneal macrophages that are laden with proIL-1 $\beta$, but lavage of the peritoneal cavities of these mice yields minimal quantities of the mature cytokine species. Following a subsequent intraperitoneal injection of ATP into the LPS-primed animals, however, large quantities of mature IL-1 $\beta$ are recovered in the lavage fluids [99]. Thus, ATP acts as an effective agonist of IL-1 $\beta$ posttranslational processing both in vitro and in vivo.

Subsequent studies demonstrated that ATP is an effective stimulus for promoting IL-1 $\beta$ posttranslational processing by a number of different cell types including human monocytes/macrophages [100-102] and human and mouse microglial cells [103-105]. In all cases, the cytokine response requires concentrations of ATP $>1 \mathrm{mM}$, a requirement consistent with activation of the $\mathrm{P} 2 \mathrm{X}_{7}$ receptor. Involvement of the $\mathrm{P} 2 \mathrm{X}_{7}$ receptor is further supported by the observation that KN62 inhibits ATP-induced IL-1 $\beta$ posttranslational processing by LPS-activated human monoctyes [102]; this agent is a potent inhibitor of $\mathrm{P} 2 \mathrm{X}_{7}$ receptor-mediated functions [106, 107]. Furthermore, an antibody generated against the $\mathrm{P} 2 \mathrm{X}_{7}$ receptor blocks ATPinduced IL-1 $\beta$ release from LPS-activated human monocytes [108]. Analysis of peritoneal macrophages obtained from mice genetically engineered to lack the $\mathrm{P}_{2} \mathrm{X}_{7}$ receptor provided the final piece of evidence that $\mathrm{P}_{2} \mathrm{X}_{7}$ receptor function is necessary for ATP-induced IL-1 $\beta$ posttranslational processing [26]. Macrophages obtained from both wild type and $\mathrm{P} 2 \mathrm{X}_{7}$-deficient mice generate equivalent quantities of newly synthesized proIL-1 $\beta$ in response to LPS challenge. However, in the absence of a secondary stimulus neither macrophage population releases mature IL$1 \beta$ to the medium. Following treatment with $5 \mathrm{mM}$ ATP, wild type but not $\mathrm{P} 2 \mathrm{X}_{7}$ receptor-deficient macrophages externalize large quantities of mature IL- $1 \beta$. In contrast, both macrophage populations release mature IL- $1 \beta$ when treated with the potassium ionophore nigericin, indicating that the $\mathrm{P}_{2} \mathrm{X}_{7}$ receptor-deficient macrophages are competent to process proIL-1 $\beta$ but absence of the $\mathrm{P} 2 \mathrm{X}_{7}$ receptor prevents them from doing so when challenged with ATP [26].

Signaling pathways associated with $\mathrm{P} 2 X_{7}$ receptor activation Mechanistic elements engaged as a result of $\mathrm{P} 2 \mathrm{X}_{7}$ receptor activation that are responsible for initiating IL- $1 \beta$ posttranslational processing are not completely understood, but studies to date have provided insight into this atypical secretory process. ATP acting via the $\mathrm{P}_{2} \mathrm{X}_{7}$ receptor activates a number of intracellular kinases including members of the MAP kinase family ERK and JNK [23, 109-112], Rho effector kinases [113, 114], and the protein tyrosine kinase $\mathrm{p} 56^{\text {lck }}$ [115]. Correspondingly, increased phosphorylation of various intracellular polypeptides including the receptor itself are observed post-ATP activation [116-118]. $\mathrm{P} 2 \mathrm{X}_{7}$ receptor operation also is associated with activation of various transcription factors [119, 120], enhanced production of reactive oxygen species [121], mitochondrial membrane depolarization [122], and activation of phospholipase D [123]. It remains to be established whether any of these changes are required for IL-1 $\beta$ posttranslational processing, although a $\mathrm{Ca}^{2+}$-independent phospholipase inhibitor (bromoenol lactone) and a tyrosine kinase inhibitor (AG-126) are reported to inhibit ATPinduced IL-1 $\beta$ output $[124,125]$. As a ligand-gated ion channel, the $\mathrm{P} 2 \mathrm{X}_{7}$ receptor also promotes rapid changes in ionic homeostasis following its activation [126]. Prolonged ligation of the receptor can result in complete membrane depolarization, a process that is likely to involve opening of the $\mathrm{P} 2 \mathrm{X}_{7}$ receptor operated pore [126]. In several cellular systems, a rise in intracellular $\mathrm{Ca}^{2+}$ promoted by the $\mathrm{P} 2 \mathrm{X}_{7}$ receptor is necessary for IL- $1 \beta$ posttranslational processing $[127,128]$. Similarly, $\mathrm{K}^{+}$efflux mediated via $\mathrm{P}_{2} \mathrm{X}_{7}$ receptor activation in LPS-stimulated monocytes and macrophages is necessary for efficient IL- $1 \beta$ posttranslational processing $[96,97,100,101,125,127]$. Simply increasing the medium $\mathrm{K}^{+}$ion concentration can completely inhibit ATP-induced IL-1 $\beta$ output $[96,100,101,129]$; as such, $\mathrm{K}^{+}$efflux appears to serve a key role in the cellular process.

How these changes to intracellular $\mathrm{K}^{+}$and $\mathrm{Ca}^{2+}$ ion levels regulate IL-1 $\beta$ posttranslational processing remains to be established. In the case of $\mathrm{K}^{+}$, the $\mathrm{P}_{2} \mathrm{X}_{7}$ receptorinduced changes may facilitate activation of caspase-1. As 
noted earlier, procaspase-1 is expressed constitutively by monocytes and macrophages and resides in the cytoplasmic compartment as a latent zymogen. Ligation of the $\mathrm{P}_{2} \mathrm{X}_{7}$ receptor leads to rapid activation of caspase- 1 and, like mature IL-1 $\beta$, the activated protease is released to the medium [130]. Recent studies have indicated that activation of procaspase-1 requires assembly of a large protein scaffold termed the inflammasome [131, 132]. Components of the inflammasome may include a NALP (NALP1, 2 or 3 ), the speck like protein ASC, and procaspase-5 [132135]. The importance of ASC in ATP-induced IL- $1 \beta$ posttranslational processing is highlighted by the demonstration that LPS-activated peritoneal macrophages isolated from ASC-deficient mice fail to generate mature IL-1 $\beta$ in response to ATP challenge [136]. In a resting cell, the NALP polypeptide appears to exist in an inactive monomeric conformation, but this polypeptide may undergo a conformational change in response to an appropriate effector leading to its association with ASC and procaspases [135]. This association involves several proteinprotein interaction domains including PYRIN and caspase recruitment domains (CARDs). The resulting protein ensemble positions the procaspases in close proximity leading to their proteolytic activation [135]. Studies of inflammasome assembly using broken cell preparations have demonstrated that extracts prepared from cells briefly treated with $\mathrm{mM}$ concentrations of ATP are more effective at generating mature caspase- 1 and mature IL- $1 \beta$ than are comparable extracts prepared from non-ATP treated cells. Moreover, when the ATP treatment is performed in the presence of high extracellular $\mathrm{K}^{+}$(thus limiting $\mathrm{K}^{+}$efflux from the ATP-treated cells), the resultant inflammasome activity in the cell-free extract is reduced [125]. These findings, therefore, suggest that $\mathrm{K}^{+}$efflux may facilitate inflammasome assembly and/or its activation.

As noted above, changes in intracellular $\mathrm{Ca}^{2+}$ levels also contribute to IL- $1 \beta$ posttranslational processing. ATPinduced changes in intracellular $\mathrm{Ca}^{+2}$ may result from $\mathrm{Ca}^{2+}$ entry via $\mathrm{P} 2 \mathrm{X}$ receptors as well as from $\mathrm{Ca}^{2+}$ release from intracellular stores mediated via P2Y receptors. In LPSactivated mouse peritoneal macrophages, $\mathrm{Ca}^{2+}$ release from intracellular stores is required for ATP-induced IL-1 $\beta$ maturation and release, but in this system the cytokine response does not require $\mathrm{Ca}^{2+}$ influx from the medium [127]. Likewise, ATP-induced IL-1 $\beta$ output from LPSactivated human monocytes is unaffected by removal of extracellular $\mathrm{Ca}^{2+}$ [129]. However, LPS-activated human THP-1 cells [137] and HEK293 engineered to express both the $\mathrm{P} 2 \mathrm{X}_{7}$ receptor and mature IL-1 $\beta$ [128] require influx of extracellular $\mathrm{Ca}^{2+}$ for optimal cytokine output. Therefore, the nature of the $\mathrm{Ca}^{2+}$ requirement is dependent on the type of cell being analyzed. Interestingly, a recent study concluded that opening of the $\mathrm{P} 2 \mathrm{X}_{7}$ receptor-activated pore is depen- dent on $\mathrm{Ca}^{2+}$ [138]. Although a role for the pore in IL-1 $\beta$ posttranslational processing has not been established, perhaps the $\mathrm{Ca}^{2+}$ requirement for IL-1 maturation and release relates to this activity. Moreover, $\mathrm{Ca}^{2+}$ influx via the $\mathrm{P} 2 \mathrm{X}_{7}$ receptor recently was linked to a pseudoapoptotic state characterized by phosphatidylserine movements within the plasma membrane and to cytoskeletal disruption and zeiotic membrane distortions [139].

Externalization of mature $I L-1 \beta$ following $P 2 X_{7}$ receptor activation $\mathrm{A}$ number of different mechanisms have been proposed to explain how mature IL- $1 \beta$ is released to the extracellular environment following ATP stimulation. LPSactivated murine peritoneal macrophages and human monocytes exposed to $\mathrm{mM}$ concentrations of ATP in vitro release mature IL- $1 \beta$ via a process that is accompanied by release of the cytoplasmic marker enzyme LDH $[98,140]$. Although the kinetics of appearance of LDH within the medium of ATP-treated mouse peritoneal macrophages lags behind the appearance of mature IL-1 $\beta$ [140], release of the former to the medium suggests that plasma membrane latency is lost during the ATP-induced process. Thus, one mechanism proposed for the release of mature IL- $1 \beta$ is that the producing cell dies, possibly via an apoptotic-like process, and intracellular components are released passively from the cell following disruption of the plasma membrane [98]. On the other hand, evidence exists to suggest that release of mature IL- $1 \beta$ is a facilitated process. For example, release of mature IL-1 $\beta$ from LPS-activated murine macrophages in response to ATP challenge is blocked by non-selective agents that are known to antagonize transport function of $\mathrm{ABC} 1$, a membrane-bound protein that functions in cholesterol transport [141]. On this basis, $\mathrm{ABC} 1$ was proposed to facilitate transport of mature IL-1 $\beta$ [141]. Moreover, when LPS-activated THP-1 cells are treated with $300 \mu \mathrm{M}$ BZATP, microvesicles which contain bioactive IL-1 $\beta$ are rapidly shed from the cell surface [137]. A similar process has been reported to occur in mixed cultures of rat primary astrocytes and microglia [142]. In this case, ATP released from astrocytes appears to promote shedding of microvesicles from neighboring microglia containing IL-1 $\beta$. Details of how the shed microvesicles subsequently release their content of cytokine have yet to be defined. An even more elaborate system for externalization of mature IL-1 $\beta$ has been proposed based on immunohistochemical observations that co-localized proIL-1 $\beta$ and lysosomal enzymes within cytoplasmic vesicles $[143,144]$. In response to ATP, these vesicles appear to fuse with the plasma membrane via a process that is triggered by $\mathrm{K}^{+}$depletion and dependent on phospholipase activation [144]. To what extent each of these different mechanisms contributes to the release of IL-1 $\beta$ in vivo remains to be established. 
ATP's ability to promote IL- $1 \beta$ posttranslational processing in vitro via the $\mathrm{P}_{2} \mathrm{X}_{7}$ receptor is well documented, but evidence demonstrating that the $\mathrm{P}_{2} \mathrm{X}_{7}$ receptor functions in this capacity in vivo is limited. Moreover, no evidence has thus far been presented to suggest that $\mathrm{P} 2 \mathrm{X}_{7}$ receptor levels and/or activity are altered in human inflammatory diseases. A number of single nucleotide polymorphisms have been identified in the human $\mathrm{P}_{2} \mathrm{X}_{7}$ receptor gene [145-151] and these can lead to impaired ATP-induced IL-1 $\beta$ (and IL-18) posttranslational processing in vitro $[152,153]$. Thus, it will be of great interest to determine whether individuals possessing these functionally impaired $\mathrm{P} 2 \mathrm{X}_{7}$ receptor phenotypes are less susceptible to inflammatory disorders. Two independent $\mathrm{P} 2 \mathrm{X}_{7}$ receptordeficient mouse lines have been generated [26, 154]. Although these receptor-deficient mice are overtly normal, when subjected to various challenges they display attenuated inflammatory responses. For example, after treatment with a panel of anticollagen antibodies to induce an RAlike disease state, joints recovered from wild type mice display a more pronounced inflammatory cell infiltrate and greater cartilage destruction than do joints recovered from $\mathrm{P}_{2} \mathrm{X}_{7}$ receptor-deficient mice [26]. In similar murine models of arthritis, administration of neutralizing anti-IL-1 antibodies are known to suppress the inflammatory response [155-157]. Therefore, the protection afforded by deletion of the $\mathrm{P} 2 \mathrm{X}_{7}$ receptor is consistent with the knockout mice possessing a diminished capacity to generate mature IL-1 $\beta$. Indeed, following intraplantar injection of Freund's complete adjuvant, extracts of the injected paws obtained from wild type mice contain greater levels of IL-1 $\beta$ than do comparable extracts obtained from $\mathrm{P}_{2} \mathrm{X}_{7}$ receptor-deficient mice [154]. Moreover, $\mathrm{P} 2 \mathrm{X}_{7}$ receptordeficient mice display less hypersensitivity to the adjuvant challenge than do their wild type counterparts. These in vivo disease model studies, therefore, suggest that antagonism of the $\mathrm{P}_{2} \mathrm{X}_{7}$ receptor may offer a novel therapeutic approach for the treatment of inflammatory disorders. As several pharmaceutical companies appear to be engaged in a search for antagonists of the $\mathrm{P}_{2} \mathrm{X}_{7}$ receptor [158-160], the ability to selectively modulate this receptor pharmacologically in animal models and man may soon be possible.

\section{References}

1. Fischer A (2001) Primary immunodeficiency diseases: an experimental model for molecular medicine. Lancet 357:1863-1869

2. Casanova J-L, Abel L (2004) The human model: a genetic dissection of immunity to infection in natural conditions. Nat Rev Immunol 4:55-66

3. Billiau A, Heremans H, Matthys P (2003) The use of cytokine knockouts in animal models of autoimmune disease. In:
Fantuzzi G (ed) Cytokine knockouts, 2nd edn. Humana, Totowa, NJ, pp 33-55

4. Bathon JM, Martin RW, Fleischman RM et al (2000) A comparison of etanercept and methotrexate in patients with early rheumatoid arthritis. N Engl J Med 343:1586-1593

5. Lipsky PE, van der Heijde DM, St. Clair EW et al (2000) Infliximab and methotrexate in the treatment of rheumatoid arthritis. Antitumor necrosis factor trial in rheumatoid arthritis with concomitant therapy study group. N Engl J Med 343:1594-1602

6. Doan T, Massarotti E (2005) Rheumatoid arthritis: an overview of new and emerging therapies. J Clin Pharmacol 45:751-762

7. Cohen S, Hurd E, Cush J et al (2002) Treatment of rheumatoid arthritis with Ankinra, a recombinant human interleukin-1 receptor antagonist, in combination with methotrexate. Arthritis Rheum 46:614-624

8. Hawkins PN, Lachmann HJ, Aganna E et al (2004) Spectrum of clinical features in Muckle-Wells syndrome and response to Anakinra. Arthritis Rheum 50:607-612

9. Lovell DJ, Bowyer SL, Solinger AM (2005) Interleukin-1 blockade by Anakinra improves clinical symptoms in patients with neonatal-onset multisystem inflammatory disease. Arthritis Rheum 52:1283-1286

10. Kauffman CL, Aria N, Toichi E et al (2004) A phase I study evaluating the safety, pharmacokinetics, and clinical response of a human IL-12 p40 antibody in subjects with plaque psoriasis. J Invest Dermatol 123:1037-1044

11. Mannon PJ, Fuss IJ, Mayer L et al (2004) Anti-interleukin-12 antibody for active Crohn's disease. N Engl J Med 351:20692079

12. Di Virgilio F, Chiozzi P, Ferrari D et al (2001) Nucleotide receptors: an emerging family of regulatory molecules in blood cells. Blood 97:587-600

13. Di Virgilio F, Baricordi OR, Romagnoli R et al (2005) Leukocyte P2 receptors: a novel target for anti-inflammatory and anti-tumor therapy. Curr Drug Targets: Cardiovasc Hematol Disord 5:85-99

14. Dubyak GR, Cliffor EE, Humphreys BD et al (1996) Expression of multiple ATP receptor subtypes during the differentiation and inflammatory activation of myeloid leukocytes. Drug Dev Res 39:269-278

15. Jin J, Dasari VR, Sistare FD et al (1998) Distribution of $\mathrm{P} 2 \mathrm{Y}_{2}$ receptor subtypes on haematopoietic cells. $\mathrm{Br} \mathrm{J}$ Pharmacol 123:789-794

16. Gudipaty L, Humphreys BD, Buell G et al (2001) Regulation of $\mathrm{P}_{2} \mathrm{X}_{7}$ nucleotide receptor function in human monocytes by extracellular ions and receptor density. Am J Physiol Cell Physiol 280:C943-C953

17. Wiley JS, Dubyak GR (1989) Extracellular adenosine triphosphate increases cation permeability of chronic lymphocytic leukemic lymphocytes. Blood 73:1316-1323

18. Gu B, Bendall LJ, Wiley JS (1998) Adenosine triphosphateinduced shedding of CD23 and L-selectin (CD62L) from lymphocytes is mediated by the same receptor but different metalloproteases. Blood 92:946-951

19. Gu BJ, Zhnag WY, Bendall LJ et al (2000) Expression of P2X purinoceptors on human lymphocytes and monocytes: evidence for non-functional $\mathrm{P}_{2} \mathrm{X}_{7}$ receptors. Am J Physiol Cell Physiol 279:C1189-C1197

20. Sluyter R, Barden JA, Wiley JS (2001) Detection of P2X purinergic receptors on human B lymphocytes. Cell Tissue Res 304:231-236

21. Adinolfi E, Melchiorri L, Falzoni S et al (2002) $\mathrm{P} 2 \mathrm{X}_{7}$ receptor expression in evolutive and indolent forms of chronic $\mathrm{B}$ lymphocytic leukemia. Blood 99:706-708

22. Suh B-C, Kim J-S, Namgung U et al (2001) $\mathrm{P} 2 \mathrm{X}_{7}$ nucleotide receptor mediation of membrane pore formation and superoxide 
generation in human promyelocytes and neutrophils. J Immunol 166:6754-6763

23. Bulanova E, Budagian V, Orinska Z et al (2005) Extracellular ATP induces cytokine expression and apoptosis through $\mathrm{P}_{2} \mathrm{X}_{7}$ receptor in murine mast cells. J Immunol 174:3880-3890

24. Idzko M, Panther E, Bremer HC et al (2003) Stimulation of P2 purinergic receptors induces the release of eosinophil cationic protein and interleukin-8 from human eosinophils. Br J Pharmacol 138:1244-1250

25. Chen Y-W, Donnelly-Roberts DL, Namovic MT et al (2005) Pharmacological characterization of $\mathrm{P}_{2} \mathrm{X}_{7}$ receptors in rat peritoneal macrophages. Inflamm Res 54:119-126

26. Solle M, Labasi J, Perregaux DG et al (2001) Altered cytokine production in mice lacking $\mathrm{P} 2 \mathrm{X}_{7}$ receptors. J Biol Chem 276:125-132

27. Sung S-SJ, Young JD-E, Origlio AM et al (1985) Extracellular ATP perturbs transmembrane ion fluxes, elevates cytosolic $\left[\mathrm{Ca}^{2+}\right]$, and inhibits phagocytosis in mouse macrophages. J Biol Chem 260:13442-13449

28. Steinberg TH, Newman AS, Swanson JA et al (1987) ATP ${ }^{4-}$ permeabilizes the plasma membrane of mouse macrophages to fluorescent dyes. J Biol Chem 262:8884-8888

29. Surprenant A, Rassendren F, Kawashima E et al (1996) The cytolytic $\mathrm{P}_{2 \mathrm{Z}}$ receptor for extracellular ATP identified as a $\mathrm{P} 2 \mathrm{X}$ receptor $\left(\mathrm{P} 2 \mathrm{X}_{7}\right)$. Science 272:735-738

30. Chessell IP, Simon J, Hibell AD et al (1998) Cloning and functional characterization of the mouse $\mathrm{P} 2 \mathrm{X}_{7}$ receptor. FEBS Lett 439:26-30

31. Coutinho-Silva R, Ojcius DM, Gorecki DC et al (2004) Multiple $\mathrm{P} 2 \mathrm{X}$ and P2Y receptor subtypes in mouse J774, spleen and peritoneal macrophages. Biochem Pharmacol 69:641-655

32. Ferrari D, Chiozzi P, Falzoni S et al (1997) ATP-mediated cytotoxicity in microglial cells. Neuropharmacology 36:12951301

33. Collo G, Neidhart S, Kawashima E et al (1997) Tissue distribution of the $\mathrm{P}_{2} \mathrm{X}_{7}$ receptor. Neuropharmacology 36:1277-1283

34. Hickman SE, El Khoury J, Greenberg $S$ et al (1994) $\mathrm{P} 2 \mathrm{Z}$ adenosine triphosphate receptor activity in cultured human monocyte-derived macrophages. Blood 84:2452-2456

35. Falzoni S, Munerati M, Ferrari D et al (1995) The purinergic $\mathrm{P} 2_{\mathrm{Z}}$ receptor of human macrophage cells. Clin Invest 95:1207-1216

36. Humphreys BD, Dubyak GR (1996) Induction of the $\mathrm{P} 2_{\mathrm{Z}} / \mathrm{P} 2 \mathrm{X}_{7}$ nucleotide receptor and associated phospholipase activity by lipopolysaccharide and IFN- $\gamma$ in the human THP-1 monocytic cell line. J Immunol 157:5627-5637

37. Berchtold S, Ogilvie ALJ, Bogdan C et al (1999) Human monocyte derived dendritic cells express functional P2X and $\mathrm{P} 2 \mathrm{Y}$ receptors as well as ecto-nucleotidases. FEBS Lett 458:424-428

38. Ferrari D, La Sala A, Chiozzi P et al (2000) The P2 purinergic receptors of human dendritic cells: identification and coupling to cytokine release. FASEB J 14:2466-2476

39. Zhang FL, Luo L, Gustafson E et al (2002) P2 $Y_{13}$ : identification and characterization of a novel G $\alpha$ i-coupled ADP receptor from human and mouse. J Pharmacol Exp Ther 301:705-713

40. Mutini C, Falzoni S, Ferrari D et al (1999) Mouse dendritic cells express the $\mathrm{P}_{2} \mathrm{X}_{7}$ purinergic receptor: characterization and possible participation in antigen presentation. J Immunol 163:1958-1965

41. Ralevic V, Burnstock G (1998) Receptors for purines and pyrimidines. Pharmacol Rev 50:413-492

42. Luster AD (1998) Chemokines-chemotactic cytokines that mediate inflammation. N Engl J Med 338:436-455

43. Mukaida N (2003) Pathophysiological roles of interleukin-8/ CXCL8 in pulmonary diseases. Am J Physiol Lung Cell Mol Physiol 284:L566-L577
44. Warny M, Aboudola S, Robson SC et al (2001) P2 $\mathrm{Y}_{6}$ nucleotide receptor mediates monocyte interleukin- 8 production in response to UDP or lipopolysaccharide. J Biol Chem 276:26051-26056

45. Cox MA, Gomes B, Plamer K et al (2005) The pyrimidinergic $\mathrm{P}^{2} \mathrm{Y}_{6}$ receptor mediates a novel release of proinflammatory cytokines and chemokines in monocytic cells stimulated with UDP. Biochem Biophys Res Commun 330:467-473

46. Dubyak GR, el-Moatassim C (1993) Signal transduction via P2purinergic receptors for extracellular ATP and other nucleotides. Am J Physiol 265:C577-C606

47. Boeynaems J-M, Communi D, Gonzalez NS et al (2005) Overview of the P2 receptors. Semin Thromb Hemost 31:139149

48. Korcok J, Raimundo LN, Du X et al (2005) P2Y 6 nucleotide receptors activate NF- $\mathrm{KB}$ and increase survival of osteoclasts. J Biol Chem 280:16909-16915

49. Baeuerle PA, Henkel T (1994) Function and activation of NF-kB in the immune system. Annu Rev Immunol 12:141-179

50. Dolmetsch RE, Xu K, Lewis RS (1998) Calcium oscillations increase the efficiency and specificity of gene expression. Nature 392:933-936

51. Somers GR, Hammett FMA, Trute L et al (1998) Expression of the $\mathrm{P}_{2} \mathrm{Y}_{6}$ purinergic receptor in human $\mathrm{T}$ cells infiltrating inflammatory bowel disease. Lab Invest 78:1375-1383

52. Trinchieri G (2003) Interleukin-12 and the regulation of innate resistance and adaptive immunity. Nat Rev Immunol 3:133-146

53. Trinchieri G, Pflanz S, Kastelein RA (2003) The IL-12 family of heterodimeric cytokines: new players in the regulation of $\mathrm{T}$ cell responses. Immunity 19:641-644

54. Langrish CL, McKenzie BS, Wilson NJ et al (2004) IL-12 and IL-23: master regulators of innate and adaptive immunity. Immunol Rev 202:96-105

55. Watford WT, Hissong BD, Bream JH et al (2004) Signaling by IL-12 and IL-23 and the immunoregulatory roles of STAT4. Immunol Rev 202:139-156

56. Aggarwal S, Ghilardi N, Xie M-H et al (2003) Interleukin-23 promotes a distinct CD4 $\mathrm{T}$ cell activation state characterized by the production of interleukin-17. J Biol Chem 278:1910-1914

57. Langrish CL, Chen Y, Blumenschein WM et al (2005) IL-23 drives pathogenic $\mathrm{T}$ cell population that induces autoimmune inflammation. J Exp Med 201:233-240

58. Moss RB, Moll T, El-Kalay M et al (2005) Th1/Th2 cells in inflammatory disease states: therapeutic implications. Expet Opin Biol Ther 4:1887-1896

59. Schnurr M, Then F, Galambos P et al (2000) Extracellular ATP and TNF- $\alpha$ synergise in the activation and maturation of human dendritic cells. J Immunol 165:4704-4709

60. la Salla A, Sebastiani S, Ferrari D et al (2002) Dendritic cells exposed to extracellular adenosine triphosphate acquire the migratory properties of mature cells and show a reduced capacity to attract type $1 \mathrm{~T}$ lymphocytes. Blood 99:1715-1722

61. la Sala A, Ferrari D, Corinti S et al (2001) Extracellular ATP induces a distorted maturation of dendritic cells and inhibits their capacity to initiate Th1 responses. J Immunol 166:1611-1617

62. Wilkin F, Duhant X, Bruyns C et al (2001) The P2 $\mathrm{Y}_{11}$ receptor mediates the ATP-induced maturation of human monocytederived dendritic cells. J Immunol 166:7172-7177

63. Wilkin F, Stordeur P, Goldman M et al (2002) Extracellular adenine nucleotides modulate cytokine production by human monocyte-derived dendritic cells: dual effect on IL-12 and stimulation of IL-10. Eur J Immunol 32:2409-2417

64. D'Andrea A, Rengaraju M, Valiante NM et al (1992) Production of natural killer cell stimulatory factor (interleukin 12) by peripheral blood mononuclear cells. J Exp Med 176:1387-1398

65. Schnurr M, Toy T, Shin A et al (2005) Extracellular nucleotide signaling by P2 receptors inhibits IL-12 and enhances IL-23 
expression in human dendritic cells: a novel role for the cAMP pathway. Blood 105:1582-1589

66. Oppmann B, Lesley R, Blom B et al (2000) Novel p19 protein engages IL-12p40 to form a cytokine, IL-23, with biological properties similar as well as distinct from IL-12. Immunity $13: 715-725$

67. Marteau F, Communi D, Boeynaems J-M et al (2004) Involvement of multiple $\mathrm{P} 2 \mathrm{Y}$ receptors and signaling pathways in the action of adenine nucleotide diphosphates on human monocytederived dendritic cells. J Leukoc Biol 76:796-803

68. Narumiya S, Sugimoto Y, Ushikubi F (1999) Prostanoid receptors: structures, properties, and functions. Physiol Rev 79:1193-1225

69. Nataraj C, Thomas DW, Tilley SL et al (2001) Receptors for prostaglandin $\mathrm{E}_{2}$ that regulate cellular immune responses in the mouse. J Clin Invest 108:1229-1235

70. Braun MC, Kelsall BL (2001) Regulation of interleukin-12 production by G-protein-coupled receptors. Microbes Infect 3:99-107

71. Granstein RD, Ding W, Huang J et al (2005) Augmentation of cutaneous immune responses by ATP $\gamma \mathrm{S}$ : purinergic agonists define a novel class of immunologic adjuvants. J Immunol 174:7725-7731

72. Mizumoto N, Kumamoto T, Robson SC et al (2002) CD39 is the dominant Langehans cell-associated ecto-NTPDase: modulatory roles in inflammation and immune responsiveness. Nat Med $8: 358-365$

73. Jarvis MF, Burgard EC, McGaraughty S et al (2002) A-317491, a potent and selective non-nucleotide antagonist of $\mathrm{P} 2 \mathrm{X}_{3}$ and $\mathrm{P} 2 \mathrm{X}_{2}$ 3 receptors, reduces chronic inflammatory and neuropathic pain in the rat. Proc Nat Acad Sci 99:17179-17184

74. Gargett CE, Cornish JE, Wiley JS (1997) ATP, a partial agonist for the P2Z receptor of human lymphocytes. Br J Pharmacol 122:911-917

75. Bianchi BR, Lynch KJ, Touma E et al (1999) Pharmacological characterization of recombinant human and rat $\mathrm{P} 2 \mathrm{X}$ receptor subtypes. Eur J Pharmacol 376:127-138

76. Murgia M, Hanau S, Pizzo P et al (1993) Oxidized ATP; an irreversible inhibitor of the macrophage purinergic $\mathrm{P} 2 \mathrm{X}$ receptor. J Biol Chem 268:8199-8203

77. Beigi RD, Kertesy SB, Aquilina G et al (2003) Oxidized ATP (oATP) attenuates proinflammatory signaling via P2 receptorindependent mechanisms. Br J Pharmacol 140:507-519

78. Hide I, Tanaka M, Inoue A et al (2000) Extracellular ATP triggers tumor necrosis factor- $\alpha$ release from rat microglia. $\mathrm{J}$ Neurochem 75:965-972

79. Tonetti M, Sturla L, Giovine M et al (1995) Extracellular ATP enhances mRNA levels of nitric oxide synthase and TNF $\alpha$ in lipopolysaccharide-treated RAW 264.7 murine macrophages. Biochem Biophys Res Commun 214:125-130

80. Hasko G, Kuhel DG, Salzman AL et al (2000) ATP suppression of interleukin-12 and tumour necrosis factor- $\alpha$ release from macrophages. Br J Pharmacol 129:909-914

81. Kucher BM, Neary JT (2005) Bi-functional effects of ATP/P2 receptor activation on tumor necrosis factor-alpha release in lipopolysaccharide-stimulated astrocytes. J Neurochem 92:525535

82. Dinarello CA (1998) Interleukin-1, interleukin-1 receptors and interleukin-1 receptor antagonist. Int Rev Immunol $16: 457-499$

83. Cerretti DP, Lozlosky CJ, Mosley B et al (1992) Molecular cloning of the interleukin-1 $\beta$ converting enzyme. Science 256:97-100

84. Thornberry NA, Bull HG, Calaycay JR et al (1992) A novel heterodimeric cysteine protease is required for interleukin- $1 \beta$ processing in monocytes. Nature 356:768-774
85. Kuida K, Lippke JA, Ku G et al (1995) Altered cytokine export and apoptosis in mice deficient in interleukin- $1 \beta$ converting enzyme. Science 267:2000-2002

86. Ayala JM, Yamin TT, Egger LA et al (1994) IL-1 $\beta$-converting enzyme is present in monocytic cells as an inactive $45 \mathrm{kDa}$ precursor. J Immunol 153:2592-2599

87. Hogquist KA, Unanue ER, Chaplin DD (1991) Release of IL-1 from mononuclear phagocytes. J Immunol 147:2181-2186

88. Bhakdi S, Muhly M, Korom S et al (1990) Effects of Escherichia coli hemolysin on human monocytes. J Clin Invest 85:1746-1753

89. Walev I, Weller U, Strauch S et al (1996) Selective killing of human monocytes and cytokine release provoked by sphingomyelinase (beta-toxin) of Staphylococcus aureus. Infect Immun 64:2974-2979

90. Verhoef PA, Kertesy SB, Estacion M et al (2004) Maitotoxin induces biphasic interleukin-1 $\beta$ secretion and membrane blebbing in murine macrophages. Mol Pharmacol 66:909-920

91. Cordoba-Rodriguez R, Fang H, Lankford CSR et al (2004) Anthrax lethal toxin rapidly activates caspase-1/ICE and induces extracellular release of interleukin (IL)-1 $\beta$ and IL-18. J Biol Chem 279:20563-20566

92. Kelk P, Claesson R, Hanstrom L et al (2005) Abundant secretion of bioactive interleukin- $1 \beta$ by human monocytes induced by Actinobacillus actinomycetemcomitans leukotoxin. Infect Immun 73:453-458

93. Perregaux D, Bhavsar K, Contillo L et al (2002) Antimicrobial peptides initiate IL- $1 \beta$ posttranslational processing: a novel role beyond innate immunity. J Immunol 168:3024-3032

94. Elssner A, Duncan M, Gavrilin M et al (2004) A novel $\mathrm{P}_{2} \mathrm{X}_{7}$ receptor activator, the human cathelicidin-derived peptide LL37, induces IL-1 $\beta$ processing and release. J Immunol 172:4987-4994

95. Perregaux D, Barberia J, Lanzetti AJ et al (1992) IL-1 $\beta$ maturation: evidence that mature cytokine formation can be induced specifically by nigericin. J Immunol 149:1294-1303

96. Walev I, Reske K, Palmer M et al (1995) Potassium-inhibited processing of IL-1 $\beta$ in human monocytes. EMBO J 14:16071614

97. Cheneval D, Ramage $P$, Kastelic $T$ et al (1998) Increased mature interleukin- $1 \beta$ (IL-1 $\beta$ ) secretion from THP- cells induced by nigericin is a result of activation of $\mathrm{p} 45$ IL- $1 \beta$-converting enzyme processing. J Biol Chem 273:17846-17851

98. Hogquist KA, Nett MA, Unanue ER et al (1991) Interleukin 1 is processed and released during apoptosis. Proc Natl Acad Sci 88:8485-8489

99. Griffiths RJ, Stam EJ, Downs J et al (1995) ATP induces the release of IL-1 from LPS primed cells in vivo. J Immunol 154:2821-2828

100. Perregaux D, Gabel CA (1994) Interleukin1- $\beta$ maturation and release in response to ATP and nigericin. $\mathrm{J}$ Biol Chem 269:15195-15203

101. Ferrari D, Chiozzi P, Falzoni S et al (1997) Extracellular ATP triggers IL- $1 \beta$ release by activating the purinerigic $\mathrm{P} 2 \mathrm{Z}$ receptor on human macrophages. J Immunol 159:1451-1458

102. Grahames CBA, Michel AD, Chessell IP et al (1999) Pharmacological characterization of ATP- and LPS-induced IL-1 $\beta$ release in human monocytes. Br J Pharmacol 127:1915-1921

103. Ferrari D, Villalba M, Chiozzi P et al (1996) Mouse microglial cells express a plasma membrane pore gated by extracellular ATP. J Immunol 156:1531-1539

104. Ferrari D, Chiozzi P, Falzoni S et al (1997) Purinergic modulation of interleukin- $1 \beta$ release from microglial cells stimulated with bacterial endotoxin. J Exp Med 185:1-4

105. Rampe D, Wang L, Ringheim GE (2004) $\mathrm{P} 2 \mathrm{X}_{7}$ receptor modulation of $\beta$-amyloid- and LPS-induced cytokine secretion 
from human macrophages and microglia. J Neuroimmunol 147:56-61

106. Gargett CE, Wiley JS (1997) The isoquinoline derivative KN-62: a potent antagonist of the P2Z-receptor of human lymphoctytes. Br J Pharmacol 122:911-917

107. Humphreys BD, Virginio C, Surprenant A et al (1998) Isoquinolines as antagonists of the $\mathrm{P}_{2} \mathrm{X}_{7}$ nucleotide receptor: high selectivity for the human versus rat receptor homologues. Mol Pharmacol 54:22-32

108. Buell G, Chessell IP, Michel AD et al (1998) Blockade of human $\mathrm{P}_{2} \mathrm{X}_{7}$ receptor function with a monoclonal antibody. Blood 92:3521-3528

109. Bradford MD, Soltoff SP (2002) $\mathrm{P} 2 \mathrm{X}_{7}$ receptors activate protein kinase (MAPK) downstream of protein kinase C. Biochem J 366:745-755

110. Amstrup J, Novak I (2003) P2X $\mathrm{X}_{7}$ receptor activates extracellular signal-regulated kinases ERK1 and ERK2 independently of $\mathrm{Ca}^{2+}$ influx. Biochem J 374:51-61

111. Auger R, Motta I, Benihoud K et al (2005) A role for mitogenactivated protein kinase $\mathrm{Erk}^{\mathrm{E} / 2}$ activation and non-selective pore formation in $\mathrm{P}_{2} \mathrm{X}_{7}$ receptor-mediated thymocyte death. $\mathrm{J}$ Biol Chem 280:28142-28151

112. Humphreys BD, Rice J, Kertesy SB et al (2000) Stress-activated protein kinase/JNK activation and apoptotic induction by the macrophage $\mathrm{P} 2 \mathrm{X}_{7}$ nucleotide receptor. J Biol Chem 275:2679226798

113. Verhoef PA, Estacion M, Schilling W et al (2003) P2X $X_{7}$ receptordependent blebbing and the activation of Rho-effector kinases, caspases, and IL-1 $\beta$ release. J Immunol 170:5728-5738

114. Pfeiffer ZA, Aga M, Prabhu U et al (2004) The neucleotide receptor $\mathrm{P} 2 \mathrm{X} 7$ mediates actin reorganization and membrane blebbing in RAW 264.7 macrophages via p38 MAP kinase and Rho. J Leukoc Biol 75:1173-1182

115. Budagian V, Bulanova E, Brovko L et al (2003) Signaling through $\mathrm{P}_{2} \mathrm{X}_{7}$ receptor in human T cells involves p56 $6^{\text {lck }}$, MAP kinases, and transcription factors AP-1 and NF- $\mathrm{kB}$. J Biol Chem 278:1549-1560

116. Adinolfi E, Kim M, Young MT et al (2003) Tyrosine phosphorylation of HSP90 within the ${\mathrm{P} 2 \mathrm{X}_{7}}_{7}$ receptor complex negatively regulates $\mathrm{P} 2 \mathrm{X}_{7}$ receptors. J Biol Chem 278:3734437351

117. Feng Y-H, Wang L, Wang Q et al (2005) ATP stimulates GRK-3 phosphorylation and B-arrestin-2-dependent internalization of

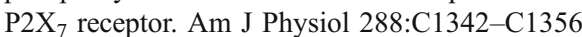

118. Kim M, Jian LH, Wilson HL et al (2001) Proteomic and functional evidence for a $\mathrm{P} 2 \mathrm{X}_{7}$ receptor signaling complex. EMBO J 20:6347-6358

119. Ferrari D, Wesselborg S, Baurer MKA et al (1997) Extracellular ATP activates transcription factor NF-kB through the P2Z purinoreceptor by selectively targeting NF-kB p65 (RelA). J Cell Biol 139:1635-1643

120. Ferrari D, Stroh C, Schulze-Osthoff K (1999) $\mathrm{P} 2 \mathrm{X}_{7} / \mathrm{P} 2 Z$ purinoreceptor-mediated activation of transcription factor NFAT in microglial cells. J Biol Chem 274:13205-13210

121. Parvathenani LK, Tertyshnikova S, Creco CR et al (2003) P2X mediates superoxide production in primary microglia and is upregulated in a transgenic mouse model of Alzheimer's disease. J Biol Chem 278:13309-13317

122. Garcia-Marcos M, Fontanils U, Aguirre A et al (2005) Role of sodium in mitochondrial membrane depolarization induced by $\mathrm{P}_{2} \mathrm{X}_{7}$ receptor activation in submandibular glands. FEBS Lett 579:5407-5413

123. Humphreys BD, Dubyak GR (1996) Induction of the P2X/P2X nucleotide receptor and associated phospholipase $\mathrm{D}$ activity by lipopolysaccharide and IFN $\gamma$ in the human THP-1 monocytic cell line. J Immunol 157:5627-5637
124. Mehta VB, Hart J, Wewers MD (2001) ATP-stimulated release of interleukin (IL)-1 $\beta$ and IL-18 requires priming by lipopolysaccharide and is independent of caspase-1 cleavage. J Biol Chem 276:3820-3826

125. Kahlenberg JM, Dubyak GR (2003) Mechanisms of caspase-1 activation by $\mathrm{P} 2 \mathrm{X}_{7}$ receptor-mediated $\mathrm{K}^{+}$release. Am J Physiol 286:C1100-C1108

126. North RA (2002) Molecular physiology of P2X receptors. Physiol Rev 82:1013-1067

127. Brough D, Le Feuvre RA, Wheeler RD et al (2003) $\mathrm{Ca}^{2+}$ stores and $\mathrm{Ca}^{2+}$ entry differentially contribute to the release of IL- $1 \beta$ and IL-1 $\alpha$ from murine macrophages. J Immunol 170:30293036

128. Gudipaty L, Munetz J, Verhoef PA et al (2003) Essential role for $\mathrm{Ca}^{2+}$ in regulation of IL- $1 \beta$ secretion by $\mathrm{P} 2 \mathrm{X}_{7}$ nucleotide receptor in monocytes, macrophages, and HEK293 cells. Am J Phyisol 285:C286-C299

129. Perregaux DG, Gabel CA (1998) Human monocyte stimuluscoupled IL-1 $\beta$ posttranslational processing: modulation via monovalent cations. Am J Physiol 275:C1538-C1547

130. Laliberte RE, Eggler J, Gabel CA (1999) ATP treatment of human monocytes promotes caspase-1 maturation and externalization. J Biol Chem 274:36944-36951

131. Martinon F, Burns K, Tschopp J (2002) The inflammasome: a molecular platform triggering activation of inflammatory caspases and processing of proIL-1 $\beta$. Mol Cell 10:417-426

132. Tschopp J, Martinon F, Burns K (2003) NALPS: a novel protein family involved in inflammation. Nat Rev Mol Cell Biol 4:95104

133. Dowds TA, Masumoto J, Zhu L et al (2004) Cryopyrin-induced interleukin $1 \beta$ secretion in monocytic cells. J Biol Chem 279:21924-21928

134. Bruey JM, Rruey-Sedano N, Newman R et al (2004) PAN1/ NALP2/PYPAF2, an inducible inflammatory mediator that regulates NF- $\mathrm{KB}$ and caspase-1 activation in macrophages. J Biol Chem 279:51897-51907

135. Martinon F, Tschopp J (2004) Inflammatory caspases: linking an intracellular innate immune system to autoinflammatory diseases. Cell 117:561-574

136. Mariathasan S, Newton K, Monack DM et al (2004) Differential activation of the inflammasome by caspase- 1 adaptors ASC and Ipaf. Nature 430:213-218

137. MacKenzie A, Wilson HL, Kiss-Toth E et al (2001) Rapid secretion of interleukin- $1 \beta$ by microvesicle shedding. Immunity 8:825-835

138. Faria RX, DeFarias FP, Alves LA (2005) Are second messengers crucial for opening the pore associated with $\mathrm{P}_{2} \mathrm{X}_{7}$ receptor? Am J Physiol 288:C260-C271

139. Mackenzie AB, Young MT, Adinolfi E et al (2005) Pseudoapoptosis induced by brief activation of ATP-gated P2X7 receptors. J Biol Chem 280:33968-33976

140. Perregaux DG, Gabel CA (1998) Post-translational processing of murine IL-1: evidence that ATP-induced release of IL- $1 \alpha$ and IL$1 \beta$ occurs via a similar mechanism. J Immunol 160:2469-2477

141. Hamon Y, Luciani M-F, Becq F et al (1997) Interleukin-1 $\beta$ secretion is impaired by inhibitors of the ATP binding cassette transporter, ABC1. Blood 90:2911-2915

142. Bianco F, Pravettoni E, Colombo A et al (2005) Astrocytederived ATP induces vesicle shedding and IL-1 $\beta$ release from microglia. J Immunol 174:7268-7277

143. Andrei C, Dazzi C, Lotti L et al (1999) The secretory route of the leaderless protein interleukin $1 \beta$ involves exocytosis of endolysosome-related vesicles. Mol Biol Cell 10:1463-1475

144. Andrei C, Margiocco P, Poggi A et al (2005) Phospholipases C and $\mathrm{A}_{2}$ control lysosome-mediated IL- $1 \beta$ secretion: implications for inflammatory processes. Proc Natl Acad Sci 101:9745-9750 
145. Wiley JS, Dao-Ung LP, Gu BJ et al (2002) A loss-of function polymorphic mutation in the cytolytic $\mathrm{P} 2 \mathrm{X}_{7}$ receptor gene and chronic lymphocytic leukemia: a molecular study. Lancet 359:1114-1119

146. Li CM, Campbell SJ, Kumararatne DS et al (2002) Response heterogeneity of human macrophages to ATP is associated with $\mathrm{P}_{2} \mathrm{X}_{7}$ receptor expression but not to polymorphisms in the $\mathrm{P}_{2} \mathrm{RX}_{7}$ promoter. FEBS Lett 531:127-131

147. Zhang LY, Ibbotson RE, Orchard JA et al (2003) $\mathrm{P} 2 \mathrm{X}_{7}$ polymorphism and chronic lymphocytic leukaemia: lack of correlation with incidence, survival and abnormalities of chromosome 12. Leukemia 17:2097-2100

148. Le Stunff H, Auger R, Kanellopoulos J et al (2004) The Pro-451 to Leu polymorphism within the C-terminal tail of $\mathrm{P}_{2} \mathrm{X}_{7}$ receptor impairs cell death but not phospholipase $\mathrm{D}$ activation in murine thymocytes. J Biol Chem 279:16918-16926

149. Skarratt KK, Fuller SJ, Sluyter R et al (2005) A 5' intronic splice site polymorphism leads to a null allele of the $\mathrm{P}_{2} \mathrm{X}_{7}$ gene in $1-$ $2 \%$ of the Caucasian population. FEBS Lett 579:2675-2678

150. Cabrini G, Falzoni S, Forchap SL et al (2005) A His-155 to Tyr polymorphism confers gain-of-function to the human $\mathrm{P}_{2} \mathrm{X}_{7}$ receptor of human leukemic lymphocytes. J Immunol 175:82-89

151. Gu BJM, Sluyter R, Skarratt KK et al (2004) An $\mathrm{Arg}^{307}$ to Gln polymorphism within the ATP-binding site causes loss of function of the human P2X 7 receptor. J Biol Chem 279:31287-31295

152. Sluyter R, Shemon AN, Wiley JS (2004) Glu ${ }^{496}$ to Ala polymorphism in the $\mathrm{P} 2 \mathrm{X}_{7}$ receptor impairs ATP-induced IL$1 \beta$ release from human monocytes. J Immunol 172:3399-3405
153. Sluyter R, Dalitz JG, Wiley JS (2004) $\mathrm{P} 2 \mathrm{X}_{7}$ receptor polymorphism impairs extracellular adenosine 5 'triphosphate-induced interleukin-18 release from human monocytes. Genes Immun 5:588-591

154. Chessell IP, Hatcher JP, Bountra $C$ et al (2005) Disruption of the $\mathrm{P} 2 \mathrm{X}_{7}$ purinoceptor gene abolishes chronic inflammatory and neuropathic pain. Pain 114:386-396

155. Joosten LA, Helsen MM, Saxne T et al (1999) IL- $1 \alpha / \beta$ blockade prevents cartilage and bond destruction in murine type II collagen-induced arthritis, whereas TNF $\alpha$ blockade only ameliorates joint inflammation. J Immunol 163:5049-5055

156. Williams RO, Marinova-Mutafchieva L, Feldmann $\mathrm{M}$ et al (2000) Evaluation of TNF $\alpha$ and IL-1 blockade in collageninduced arthritis and comparison with combined anti-TNF $\alpha$ /antiCD4 therapy. J Immunol 165:7240-7245

157. Kagari T, Doi H, Shimozato T (2002) The importance of IL-1 $\beta$ and TNF $\alpha$, and the noninvolvement of IL- 6 , in the development of monoclonal antibody-induced arthritis. J Immunol 169:14591466

158. Baxter A, Bent J, Bowers K et al (2003) Hit-to-lead studies: the discovery of potent adamantine amide $\mathrm{P} 2 \mathrm{X}_{7}$ receptor antagonists. Bioorg Med Chem Lett 13:4047-4050

159. Merriman GH, Ma L, Shum P et al (2005) Synthesis and SAR of novel 4,5-diarylimidazolines as potent $\mathrm{P} 2 \mathrm{X}_{7}$ receptor antagonists. Bioorg Med Chem Lett 15:435-438

160. Romagnoli R, Baraldi PG, Di Virgilio F (2005) Recent progress in the discovery of antagonists acting at $\mathrm{P} 2 \mathrm{X}_{7}$ receptor. Expert Opin Ther Pat 15:271-287 